\title{
Volver a soñar una casa común en la que todos vivan dignamente
}

\author{
Arturo Sosa, S.J.'
}

La Revista de Fomento Social nació con el nuevo orden mundial emanado de la debacle de la II Guerra Mundial. De forma encomiable, las naciones vencedoras y vencidas lograron en ese entonces ponerse de acuerdo para levantar sobre las cenizas de la destrucción una nueva arquitectura política, económica y financiera mundial. Después de setenta y cinco años la pregunta obligada es en qué medida se han materializado los sueños de progreso inclusivo que el nuevo orden mundial pretendía. Después de varias décadas iniciales de avances y optimismo, el mundo actual presenta niveles alarmantes de pobreza, inequidad, violencia, discriminación, injusticia, degradación humana y agresión ambiental. De ahí que foros de reflexión y discusión como esta Revista sean hoy tan relevantes y necesarios.

La crisis de la pandemia del COVID ha dejado todavía más al desnudo tendencias que se venían gestando. Al interior de los países han sido los más pobres, las minorías discriminadas, o los de menor nivel de educación los que se han visto más afectados, debido a la precariedad de los empleos y del acceso a la salud. A nivel de las naciones, los países más pobres, especialmente en África y Latinoamérica, han experimentado tasas de mortalidad brutales y caídas proporcionalmente mayores de actividad económica y empleo. Mientras que muchos de los países desarrollados van a poder alcanzar la inmunidad de rebaño en el tercer trimestre de este año 2021, la mayoría de los países africanos y latinoamericanos no podrán hacerlo hasta entrado el año 2023.

' Superior General de la Compañía de Jesús. 
El desequilibrio en el acceso a las vacunas a nivel internacional demuestra no solo la falta de solidaridad de los países ricos, sino la incapacidad de un sistema capitalista basado en principios neoliberales para solucionar un problema tan fundamental. Por la vía de las "fuerzas del mercado" no hay forma de que los pobres de los países pobres o ricos accedan a las vacunas en tiempo razonable. No sólo porque no pueden pagarlas, sino porque los conglomerados farmacéuticos dueños de las patentes se resisten a relajar temporalmente las normas de propiedad intelectual para permitirles a los países en vías de desarrollo producir localmente las vacunas. Así funciona la lógica del mercado.

Esta lógica, al igual que la prevalencia absoluta de la propiedad privada choca contra dos principios fundamentales de la doctrina social de la Iglesia, como son el "destino universal de los bienes" y el "bien común". Ha sido también en aras de esta concepción neoliberal que la globalización ha avanzado inexorablemente, que los mercados financieros se han desregulado, que la economía financiera ha tomado la supremacía sobre la economía real; los Estados nacionales se han batido en retirada frente al poder avasallante de las multinacionales y los mercados financieros mantienen cautivas las soberanías de los países a la hora de definir sus políticas económicas.

Han sido décadas de gran crecimiento y avance tecnológico, ciertamente, pero que han dejado también una secuela de inequidad y pobreza. Muchas de las causas del populismo guardan relación con los estragos que el neoliberalismo y la globalización han causado en vastos sectores de la población. De ahí a sentirse alienados frente al sistema democrático tradicional hay solo un paso. No es casual que el avance dominante del neoliberalismo y la globalización haya minado las bases de las democracias a través del surgimiento concomitante de populismos de izquierda y de derecha. Los populismos nada tienen que ver con la concepción de las naciones como pueblos que comparten una historia común, un propósito y un destino comunes, donde privan lazos de solidaridad y donde los pobladores asumen el protagonismo en el manejo de la cosa pública. En los populismos, el pueblo es objeto pasivo, no sujeto protagónico. Son los líderes populistas los que deciden por el pueblo y suplantan al pueblo. Más pronto que tarde, las instituciones que nacieron para darle marco a la participación y control democráticos son minadas desde adentro hasta convertir a las democracias en cascarones vacíos a merced de líderes autócratas.

En América Latina estamos viviendo en un triste péndulo de populismos de derecha y de izquierda. El "consenso de Washington", que dominó las políticas de desarrollo de los 80 y 90 , no solucionó los desgarros sociales al interior de nuestros pueblos. 
Mucha frustración y resentimiento en vastos sectores de la sociedad es lo que dejaron atrás los experimentos de modernización neoliberal. Que los "líderes" populistas invoquen y convoquen hoy constantemente al pueblo no significa en absoluto que el pueblo haya pasado a ser el protagonista de la vida pública, de las iniciativas sociales y económicas, o de las decisiones que lo afectan. Los protagonistas son otros con agendas propias y perversas. Mientras no sean los pobres el centro y los protagonistas de las políticas sociales y de desarrollo no lograremos salir de este vaivén tan dañino.

Este discurso de preminencia de los pobres puede despertar inquietud en medios académicos o intelectuales porque frecuentemente ha venido acompañado de políticas imprudentes, meramente distributivas, destructivas del aparato productivo o simplemente ineficientes. Tenemos muchos ejemplos de ello, particularmente en América Latina. El reto intelectual actual es, precisamente, reiterar la opción por los pobres sin embarcarse en políticas fracasadas que terminen dañando aún más a los pobres.

El desafío es crear los espacios para que los pobres participen activamente en la definición de la agenda pública, tanto en la identificación de los problemas como en la propuesta de vías de solución. Ahí es donde las ciencias sociales se engarzan para articular y darle viabilidad y sostenibilidad a las opciones que surjan del debate democrático. Si se quiere poner al pueblo de carne y hueso en primer plano, se necesita escuchar y entender qué es lo importante para él y qué mejora su bienestar. Por ejemplo, una de las distorsiones del pensamiento convencional es colocar el crecimiento del Producto Interno Bruto (la producción de bienes y servicios) como norte y guía de las políticas de desarrollo. Lo equivocado de este enfoque queda claro al constatar cómo al crecimiento de la producción no le corresponde el crecimiento del bienestar del pueblo.

No se trata de estigmatizar al capitalismo per se. ¿2Quién puede negar su tremenda energía creadora de riqueza, de innovación y de bienestar material? Sabemos lo desastroso que es sofocar el potencial productivo de millones de individuos en aras de un colectivismo castrante. El capitalismo, al igual que cualquier otro sistema socioeconómico, debe tener imbuida una dimensión moral, sin la cual esas energías creativas desembocan en exclusión de amplios sectores de la población, en relaciones de explotación y en destrucción del medio ambiente. La dimensión moral proviene de una concepción del ser humano como ser solidario, portador de derechos inalienables y responsable de contribuir al bien común, contrapuesta a concebirlo como individuo egoísta que, supuestamente, al perseguir solamente su propio beneficio genera el mayor bienestar colectivo. 
En congruencia con esta dimensión moral, debemos estar abiertos a planteamientos radicales en beneficio de las mayorías desfavorecidas. Me parece que tiene mérito, por ejemplo, la discusión sobre el derecho al trabajo como un derecho humano que debe ser garantizado, o el acceso a un techo y agua potable también como derecho humano. Si nos tomamos estos derechos en serio, las políticas sociales y económicas y la correspondiente asignación de recursos deberán experimentar un vuelco total. También deberá repensarse el papel del Estado, que necesita ser fortalecido para ejercer su papel de garante y árbitro de la moralidad de las actuaciones de los individuos y de las empresas.

No puedo dejar de mencionar el problema del medio ambiente y la naturaleza. Estamos destruyendo la casa común que Dios Padre nos regaló y les estamos arruinando el futuro a las generaciones venideras. El mensaje magistral del Papa Francisco en su Encíclica Laudato Si, resalta la estrecha interrelación entre lo social y el medio ambiente, entre la pobreza y la degradación de la naturaleza. La realidad es que la destrucción del medio ambiente afecta desproporcionalmente a los pobres. Son ellos los que sufren con más fuerza los efectos de las catástrofes naturales, como inundaciones y sequías que destruyen cultivos y causan hambrunas, - la fuerza destructiva de huracanes y violentas oscilaciones climáticas que afectan especialmente a quienes viven en hábitats precarios impulsando los crecientes flujos migratorios involuntarios.

A su vez, la degradación del medio ambiente es en gran medida consecuencia de una larga historia de sobreexplotación de los recursos naturales por parte de los países desarrollados en detrimento de mundo subdesarrollado. Baste recordar los crímenes ecológicos cometidos por las potencias coloniales en su afán de extraer recursos minerales o vegetales. Esta sobreexplotación ha continuado en la época postcolonial a través de la expansión indetenible de las empresas multinacionales ávidas de recursos naturales. En este sentido, la generación de estructuras injustas entre los países ricos y los países pobres ha estado íntimamente interconectada con la degradación del medio ambiente. Ha estado en la naturaleza del capitalismo producir lo más posible a precios más asequibles para la mayor cantidad posible de personas. La consecuencia de ello ha sido el hiperconsumismo y la consiguiente cultura del descarte en los países desarrollados, lo cual les hace titulares de una ingente deuda con el medio ambiente $y$, en consecuencia, con el mundo menos desarrollado. Si todos los países en vías de desarrollo tuvieran niveles de consumo similares a los de los países desarrollados, necesitaríamos tres planetas como la tierra para sostenerlos.

Si nos tomamos en serio la opción personal e intelectual por los pobres, es inelu- 
dible cuestionar el ritmo del crecimiento económico, especialmente en el mundo desarrollado, mientras persistan los actuales patrones degradantes de explotación de recursos naturales no renovables. Pocos quieren hablar de ello, especialmente las empresas y los políticos, pero debemos asumir el reto de reinventar los sistemas productivos y promover los avances tecnológicos que permitan preservar la calidad de vida en un contexto de cuido de la casa común y desarrollo sostenible.

Es mi deseo que la Revista siga siendo un foro donde estos y muchos otros temas se discutan con valentía, con honestidad intelectual y con pasión humanista. El momento no puede ser más retador para iniciar la andadura de los próximos setenta y cinco años. Agradezco de corazón a todo el equipo que hace posible la aparición regular de la Revista y los animo a continuar esta compleja y apasionante tarea. 